\title{
Classical and Molecular Cytogenetic Tools to Resolve the Bixa Karyotypes
}

\author{
Pedro Marcos de Almeida, Carlos Roberto Carvalho* and \\ Wellington Ronildo Clarindo
}

Laboratory of Cytogenetics and Cytometry, Departamento de Biologia Geral, Universidade Federal de Viçosa, 36570-000, Viçosa-MG, Brazil

Received August 15, 2006; accepted September 12, 2006

\begin{abstract}
Summary The cytogenetic studies performed in Bixa orellana have reported $2 n=14$ or $2 n=16$ chromosomes with little karyotypic information. In this context, an improved cytogenetic protocol using enzymatic maceration of meristematic cellular walls and digital image analysis was applied to B. orellana and B. arborea. In B. arborea, the high-resolution technique, Ag-NOR and C banding methods, and FISH using a probe of $45 \mathrm{~S}$ rDNA genes, were also performed. Prometaphasic and standard C-metaphasic chromosomes presented well-defined primary and secondary constrictions facilitated the pairing of homologues and assembly of the karyogram for the 2 species. These species showed similar karyotypes with $2 n=14$ chromosomes, being composed of 5 metacentric pairs $(1,2$, 3,4 and 6 ) and 2 submetacentric pairs (5 and 7). The chromosome 1 is approximately 2 times as long as the others and possesses the secondary constriction adjacent to the centromere, which suggests that Robertsonian translocation between 2 smaller chromosomes may have occurred during the karyotype evolution of Bixa. Additionally, the active NOR, the NOR-adjacent heterochromatic region and $18 \mathrm{~S}, 5.8 \mathrm{~S}$ and $26 \mathrm{~S}$ rDNA genes were identified in the secondary constriction of chromosome 1 .
\end{abstract}

Key words Ag-NOR banding, Bixa, C-banding, FISH, High-resolution technique, Robertsonian translocation.

The family Bixaceae presents only one genus, Bixa L., with 6 tropical species. Bixa orellana is a bush that synthesizes, in the seed coat, economically important natural dye pigments, such as the carotenoids bixin and norbixin (Scotter et al. 1998, Paiva Neto et al. 2003). Despite being classified into the same genus, Bixa arborea exhibits arboreal bearing and does not produce bixin and norbixin. Nevertheless, this species is interesting for the wood industry and used in reforestation projects (Lorenzi 1998).

Distinct authors have reported the chromosomic number only of B. orellana as $2 n=2 x=16$ (Simmonds 1954, Krishnan and Ayyangar 1987) or 2n=2x=14 (Mukherjee 1975, Morawetz 1986, Krishnan and Ayyangar 1987). J.F.R.P. Carvalho (2000. Thesis, Univ. Fed. of Viçosa) not only confirmed the number of $2 n=2 x=14$, but also showed the nucleolar organization region (NOR) active in chromosome 1. Therefore, considering the worldwide food and industrial interest for the natural pigments of Bixa (J.F.R.P. Carvalho 2000. Thesis, Univ. Fed. of Viçosa), greater cytogenetic knowledge of this plant is required in order to aid in breeding programs.

As demonstrated by other authors, the classical and molecular cytogenetic tools have been successfully applied for obtaining information from high quality plant chromosomes. Using cellular wall enzymatic maceration and dissociation of root-tips (Almeida and Carvalho 2004, Contim et al. 2005), and image capture by CCD cameras with digital image analysis softwares, chromosome im-

*Corresponding author, e-mail: ccarvalh@ufv.br 
ages permitted accurate cytogenetical characterization and measurements (Carvalho and Saraiva 1993, 1997, Guzzo et al. 2000, Bauchan and Hossain 2001, Neumann et al. 2002).

The present study was conducted in order to provide good quality cytogenetical preparations for application of the high-resolution methodology, $\mathrm{C}$ and Ag-NOR banding techniques and for localization of the 45S rDNA by FISH in $B$. arborea. In addition, some karyotype comparisons and chromosome evolution aspects were shown for B. orellana and B. arborea.

\section{Materials and methods}

\section{Plant material}

B. orellana seeds were obtained at Universidade Federal de Viçosa (UFV-MG, Brazil) and $B$. arborea seeds were supplied by the Reserva Florestal de Linhares (ES, Brazil). The analyses were carried out at the Laboratory of Cytogenetic and Cytometry, General Biology Department, UFV, Brazil.

\section{Pre-treatment and fixation}

Seeds of Bixa were germinated in a Petri dish at $30^{\circ} \mathrm{C}$ for $5 \mathrm{~d}$. Root-tips were treated with $3 \mu \mathrm{M}$ Trifluralin $\left(\right.$ Nortox $^{\circledR}$ ) and $100 \mu$ dimethyl sulfoxide (Sigma ${ }^{\circledR}$ ) solution for $18 \mathrm{~h}$ at $4^{\circ} \mathrm{C}$, subsequently washed with distilled water for $20 \mathrm{~min}$, fixed in fresh methanol: acetic acid (Merck $\left.{ }^{\circledR}\right)$ solution $(3: 1)$, with 3 solution changes, and then stored at $-20^{\circ} \mathrm{C}$. For high-resolution chromosome preparations, the roots of $B$. arborea were pre-treated, during $18 \mathrm{~h}$ at $4^{\circ} \mathrm{C}$, with a solution containing $0.1 \mathrm{mg} \mathrm{ml}^{-1}$ of ethidium bromide $\left(\operatorname{Sigma}^{\circledR}\right)$ and $0.1 \mathrm{mg} \mathrm{ml}^{-1}$ of colchicine (Sigma ${ }^{\circledR}$ ), as described by Carvalho and Saraiva (1997).

\section{Slide preparations}

Root-tips were washed and enzymatically macerated with a 1:14 Flaxzyme (Novo Ferment ${ }^{\mathrm{TM}}$ ): distilled water solution, for $1 \mathrm{~h} 45 \mathrm{~min}$ at $34^{\circ} \mathrm{C}$. Next, roots were washed for $20 \mathrm{~min}$ in distilled water and fixed again, then stored at $-20^{\circ} \mathrm{C}$. The slides were prepared as described by Carvalho and Saraiva $(1993,1997)$.

\section{Giemsa conventional staining}

Some slides were immediately stained with a $5 \%$ Giemsa $\left(\mathrm{Merck}^{\circledR}\right)$ solution in phosphate buffer $(\mathrm{pH}$ 6.8) for $5 \mathrm{~min}$, washed twice in distilled water, air-dried and placed on a hot-plate $\left(50^{\circ} \mathrm{C}\right)$.

\section{Ag-NOR banding}

The Ag-NOR banding technique was applied as described by Goodpasture and Bloom (1975), with minor modifications for plant chromosomes. Slides were aged for 3-5d, stained with 4 to 5 drops of $50 \% \mathrm{AgNO}_{3}\left(\mathrm{Merck}^{\circledR}\right)$ solution and incubated in a humid chamber at $30^{\circ} \mathrm{C}$ for $18-20 \mathrm{~h}$, in the dark. The coverslips were removed and the slides were washed in distilled water for $2 \mathrm{~min}$.

\section{$C$ banding}

$\mathrm{C}$ banding technique was based on the protocol described by Carvalho and Saraiva (1993). Two-week-old slides were treated in $5 \% \mathrm{Ba}(\mathrm{OH})_{2} \cdot 8 \mathrm{H}_{2} \mathrm{O}\left(\right.$ Ridel-Ecibra $\left.^{\circledR}\right)$ solution for $15 \mathrm{~s}$, at $56^{\circ} \mathrm{C}$, with continuous agitation. Next, the preparations were successively washed, for $5 \mathrm{~s}$, in $70 \%$ ethanol $\left(\mathrm{Merck}^{\circledR}\right)$ and methanol : acetic acid $(8: 1)$ solutions, air-dried, placed on a hot-plate $\left(50^{\circ} \mathrm{C}\right)$ and stained with 5\% Giemsa $\left(\right.$ Merck $\left.^{\circledR}\right)$ solution for $8 \mathrm{~min}$. 


\section{FISH}

FISH was performed according to the methods described by Contim et al. (2003). rDNA probes (pDm 238) containing the 45S rDNA gene of Drosophila melanogaster were labeled with biotin by nick translation, according to manual of the BIONICK kit $\left(\mathrm{GIBCO}^{\circledR}\right)$. Slides with wellspread chromosomes of $B$. arborea were incubated with $100 \mu \mathrm{g} \mathrm{ml}^{-1} \mathrm{RNase}$ in $2 \times \mathrm{SSC}(150 \mathrm{mM}$ $\mathrm{NaCl}, 15 \mathrm{mM} \mathrm{Na}$-citrate, $\mathrm{pH} \mathrm{7.0)}$ for $1 \mathrm{~h}$ in a humid chamber at $37^{\circ} \mathrm{C}$. Next, the slides were treated with $0.005 \%$ pepsin in $10 \mathrm{mM} \mathrm{HCl}$ at $37^{\circ} \mathrm{C}$ for $10 \mathrm{~min}$, washed with the same buffer, then with PBS ( $130 \mathrm{mM} \mathrm{NaCl}, 7 \mathrm{mM} \mathrm{Na}_{2} \mathrm{HPO}_{4}, 3 \mathrm{mM} \mathrm{NaH}_{2} \mathrm{PO}_{4}, \mathrm{pH}$ 7.0). Afterwards, the slides were sequentially dehydrated in $70 \%, 80 \%$ and $100 \%$ ethanol ( $3 \mathrm{~min}$ each) at room temperature, and finally air-dried. Probe amounts of $5 \mu \mathrm{l}$ ( $1 \mu \mathrm{l}$ of probe diluted in $4 \mu \mathrm{l}$ of hybridization mixture) were added to each hybridization area and the slide was covered with a $20 \times 20 \mathrm{~mm}$ coverslip and incubated for $3 \mathrm{~min}$ at $80^{\circ} \mathrm{C}$ and overnight at $37^{\circ} \mathrm{C}$. After incubation, the slides were maintained for $2 \mathrm{~min}$ in each of 2 baths of $50 \%$ formamide and in PBS at $37^{\circ} \mathrm{C}$. Signal detection was performed on slides treated with $5 \mu \mathrm{g} \mathrm{ml}^{-1}$ anti-biotin (VECTOR: SP 3000) and $10 \mu \mathrm{g} \mathrm{ml}^{-1}$ anti-goat IgG-FITC (VECTOR: FI 5000 ) for $1 \mathrm{~h}$ at room temperature. The preparations were counterstained with $100 \mu \mathrm{l}$ propidium iodide $\left(1 \mu \mathrm{g} \mathrm{ml}^{-1}\right)$, washed in phosphate-buffered saline (PBS) for $1 \mathrm{~min}$ and mounted with $15 \mu \mathrm{l}$ Vectashield.

\section{Image Analysis}

Images of the chromosomes were captured with a CoolSNAP-Pro $c f$ (Roper Scientific ${ }^{\circledR}$ ) video camera of 12 bits, assembled on an Olympus ${ }^{\mathrm{TM}}$ BX-60 fluorescence microscope with a $100 \times$ objective lens and a WB filter. The frame was digitized using the Kit Cool-SNAP Pro ${ }^{\circledR}$ and Image ProPlus $^{\circledR} 4.5$ analysis system (Media Cybernetics ${ }^{\circledR}$ ). Image analysis was performed on a Power Macintosh $\mathrm{G} 4{ }^{\circledR}$ computer, using the freely available (http://reg.ssci.liv.ac.uk) Image SXM software (Barrett 2002). This is a spin-off of the public domain image analysis application NIH Image, which was developed by Rasband (1998).

\section{Results}

The pre-treatment, fixation and slide preparations provided excellent prometaphases and standard C-metaphases exhibiting few overlapped chromosomes and well-defined primary and secondary constrictions (SC), which facilitated the pairing of homologues and assembly of the karyograms for B. orellana and B. arborea (Fig. 1a). The morphometry of the Bixa chromosomes was characterized according to the arm length (in micrometers) criteria described by Levan et al. (1964) and revised by Guerra (1986).

Cytogenetic analysis of the 2 species showed $2 n=2 x=14$, being 5 metacentric $(1,2,3,4$ and 6) and 2 submetacentric chromosome pairs ( 5 and 7 ), and the presence of one SC adjacent to the centromere of the chromosome 1 (Fig. 1a). Furthermore, the 14 chromosomes of Bixa presented lengths varying from 3.27 to $1.40 \mu \mathrm{m}$ in B. arborea (Fig. 1a) and 3.82 to $1.24 \mu \mathrm{m}$ in $B$. orellana metaphases (Fig. 1a).

The arm length ratios, the presence of SC adjacent to the centromere of chromosome 1 and the morphometric data suggest that these species are cytogenetically similar. The karyograms of Bixa also showed that the total length of chromosome 1 is, approximately, 2 times as large as the other chromosomes (Fig. 1a).

The high-resolution technique allowed the observation of a stalk stirred portion, on SC of the chromosome 1, associated with nucleoli (Fig. 1b,d). This region of $B$. arborea was confirmed to be an active NOR, by Ag-NOR banding (Fig. 1c), and $\mathrm{C}$ banding revealed heavily stained bands in the NOR-adjacent heterochromatic region (Fig. 1a). FISH analysis identified 2 sites for the 45S rDNA in B. arborea. This technique evidenced 2 strong fluorescence signals localized in the active NOR 


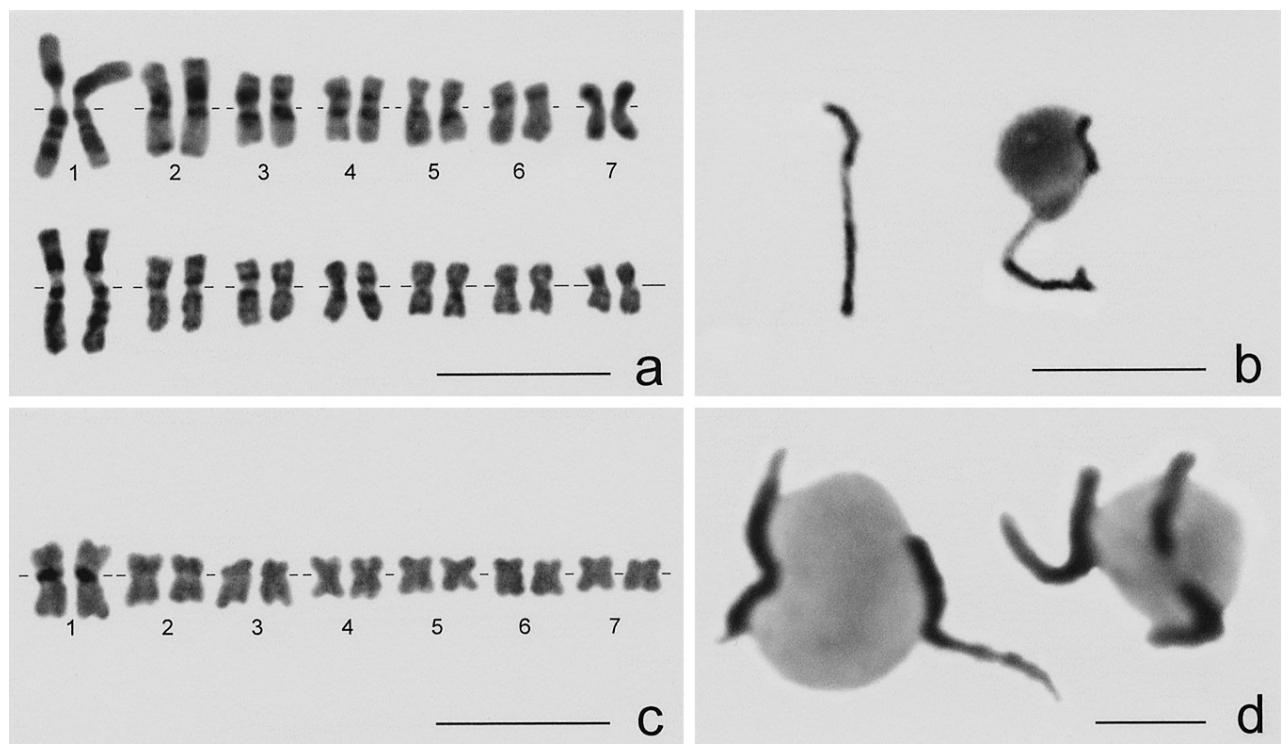

Fig. 1. Chromosomes obtained from root apical meristems of $B$. arborea or B. orellana treated with $3 \mu \mathrm{M}$ trifluralin and $100 \mu \mathrm{l}$ dimethyl sulfoxide solution for $18 \mathrm{~h}$ at $4^{\circ} \mathrm{C}$. a) the $\mathrm{C}$ banding karyograms of $B$. arborea (above) and B. orellana (below) showing positive bands in the pericentromeric and flanking NOR-adjacent regions. The Bixa karyograms possess metacentric (1 to 4 and 6) and submetacentric (5 and 7) chromosomes and the SC adjacent to the centromere of chromosome 1 . Note that the chromosome 1 possesses a total length approximately two times as large as the other chromosomes. b) B. arborea chromosomes like prophase obtained after application of high-resolution technique in root apical meristems. Chromosome 1 (left) emphasizing the stalk stirred SC and chromosome 1(right) associated to the nucleoli. c) The Ag-NOR karyogram of $B$. arborea showing the active NOR as one dark band at the SC position of chromosome 1. d) Prophasic chromosome 1 pairs nucleoli-associated. Bar $=5 \mu \mathrm{m}$.
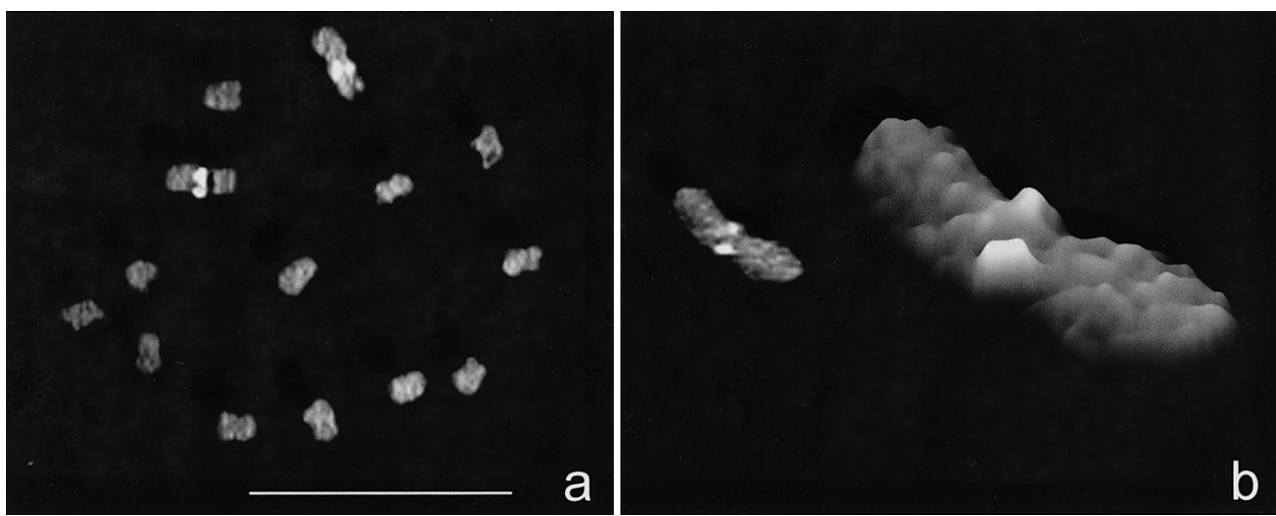

Fig. 2. B. arborea chromosomes after FISH technique showing $45 \mathrm{~S}$ rDNA sites. a) B. arborea metaphasic chromosomes showing intense fluorescence bands of the 45S rDNA sites on medial chromosome 1 . b) prometaphasic chromosome 1 (left) exhibiting two fluorescent spots of $45 \mathrm{~S}$ rDNA sites near centromeric region and a profile $3 \mathrm{D}$ density plot of the chromosome 1 (right) to highlight the rDNA sites fluorescence signals. Bar $=5 \mu \mathrm{m}$.

(Fig. 2a). The rDNA sites were illustrated by a density profile 3D plot of the chromosome 1 to highlight the fluorescence signals (Fig. 2b). 


\section{Discussion}

Microtubule inhibiting agent trifluralin was efficient in the accumulation of prometaphasic and metaphasic cells with subtle range on chromosome condensation. We considered this aspect as important for screening minor differences between chromosomes of the same class and with seemingly similar lengths (Fig. 1a).

Cell dissociation of macerated root apical meristems, associated with air-dried slide preparations, was suitable to provide clear and preserved chromosomes, evidencing the main morphological characteristics that facilitated the assembly of the Bixa karyograms (Fig. 1a). These techniques allowed the obtention of chromosomes well-spread in the same focus plane, without cytoplasmic background, overlaps or structural deformations. Identical results were obtained in Zea mays (Carvalho and Saraiva 1993, 1997), Capsicum annuum (Almeida and Carvalho 2004) and Aniba rosaeodora (Contim et al. 2005).

The CCD video camera was an efficient tool for obtaining good quality images of chromosomes due to its 12 bits information for each pixel, representing 1 of 4.096 possible gray levels with $0.12 \mu \mathrm{m} / \mathrm{pixel}$. Besides, the digital image analysis system contributed to discriminate between subtle measurements of chromosomes. Ohmido et al. (1998) and Guzzo et al. (2000) mentioned that these digital equipments are essential for capture and digitization of faint fluorescent signals.

In accordance with Murkherjee (1975), Morawetz (1986) and Carvalho et al. (2005) the $B$. orellana chomosomic number is $2 n=2 x=14$ (Fig. 1a). However, some authors found $2 n=2 x=16$ chromosomes for this species (Simmonds 1954, Krishnan and Ayyangar 1987). Morawetz (1986) related that the chromosome 1 can break in 2 fragments during slide preparations, because of the presence of SC adjacent to the centromere. This fact may have been inducing the carrying out of incorrect measurements.

Although B. orellana and B. arborea have shown a few distinct botanical characteristics, such as those concerning their bearing, color of petals and production of carotenoids (Baliane 1984, Lorenzi 1998), the arm length ratios, the presence of SC adjacent to the centromere of chromosome 1 and the morphometric data (Fig. 1a) indicate that these species are cytogenetically similar.

The chromosome 1 of both species exhibited a total length approximately 2 times as large as the other chromosomes (Fig. 1a). In that same chromosome, the stalk stirred portion on the SC of the $B$. arborea, associated to the nucleoli, was evidenced by the high-resolution technique (Fig. 1b) and the SC is clearly adjacent to the centromere (Fig. 1b). This result suggests that the Robertsonian translocation between 2 smaller chromosomes may have occurred during the evolution of Bixa. Robertsonian interchange is characterized by centromeric fusion (Jones 1998, Zhang et al. 2001, Oakey and Beechey 2002, Switonski et al. 2003) between 2 acrocentric (Gupta and Gupta 1991) or telocentric (Zhang et al. 2001) non-homologous chromosomes, resulting in one metacentric chromosome (Gupta and Gupta 1991, Jones 1998, Zhang et al. 2001, Oakey and Beechey 2002). Considering that many species present the SC in the distal portion of the short arm (Leitch and HeslopHarrison 1992, Hanson et al. 1996, Liu et al. 1997) and the morphometric data of the chromosome 1 , a break involving the long arm of 1 chromosome and the short arm of the other probably led to the formation of the metacentric chromosome 1 with the SC adjacent to the centromere, during the genomic evolution of these species.

Considering that, during mitosis, active NORs possess transcription factors of rDNA genes, that impregnate with silver (Morais-Cecílio et al. 2000, Besendorfer et al. 2002, Brasileiro-Vidal et al. 2003, Neves et al. 2005), the presence of a single active NOR was confirmed at the portion of chromosome 1 adjacent to the centromere, in B. arborea (Fig. 1c), indicating that this region contains the chromosomal domain around which nucleoli are organized at the end of mitosis, when rDNA transcription is initiated. Identical results were observed in B. orellana by Carvalho (2000).

Additional results obtained from the $\mathrm{SC}$ of $B$. arborea after $\mathrm{C}$ banding presented heavily 
stained bands at the NOR-adjacent heterochromatic region. Moreover, this technique also evidenced the pericentromeric heterochromatin in all chromosomes (Fig. 1a). Almeida and Carvalho (2004), after subjecting Zea mays and Capsicum annum chromosomes to the fluorescent banding of heterochromatin associated to the SC with the use of acridine orange (Hsc-FA banding), suggested that this NOR-adjacent heterochromatic region consists of $\beta$-heterochromatin. In addition to acridine orange, the fluorochrome chromomycin A3 has also been used to identify NOR-adjacent heterochromatin (Sato 1988, Melo and Guerra 2003, Marcon et al. 2005) in plants, indicating that this region is a GC-rich chromosomic portion.

The FISH of 45S rDNA resulted in fluorescence signals that evidenced the $18 \mathrm{~S}, 5.8 \mathrm{~S}$ and $26 \mathrm{~S}$ rDNA genes, located in the active NOR of $B$. arborea (Fig. 2a). These genes occur as a large number of tandem repeats of single transcription units ( $45 \mathrm{~s}$ rDNA). These sequences are predominantly located in the NOR of eukaryotic chromosomes (Ansari et al. 1999). Moreover, the digital image analysis system allowed the assembly of a density profile 3D plot of the chromosome 1 that highlighted the fluorescence signals (Fig. 2b). FISH proved valuable for both fundamental and applied aspects of studies of genome evolution and plant breeding (Osuji et al. 1998). Besides, this technique is a powerful tool for regional mapping of DNA sequences on chromosomes in interphase and metaphase (Ansari et al. 1999, Weiss and Maluszynska 2001).

This work represents an advance on the cytogenetics of Bixa, concerning the morphometry of the $B$. orellana and $B$. arborea chromosomes, the mitotic comparison of the 2 species and evidences of occurrence of Robertsonian translocation during the genome evolution of these species. In addition, the high quality of the chromosomes permitted the application of the techniques that identified the active NOR and characterized the NOR-adjacent heterochromatic region.

\section{Acknowledgements}

We are grateful to Dr. S. G. Pompolo, Universidade Federal de Viçosa, Brazil, for providing the labeled Drosophila rDNA probe and technical assistance, and the Fundação de Amparo à Pesquisa do Estado de Minas Gerais (FAPEMIG, BRAZIL), CNPq and CAPES, for financial support.

\section{References}

Almeida, P. M. and Carvalho, C. R. 2004. NOR-associated heterochromatin of pepper chromosomes stained with acridine orange. Caryologia 2: 177-181.

Ansari, H. A., Ellison, N. W., Reader, S. M., Badaevas, E. D., Friebe, B., Miller, T. E. and William, W. M. 1999. Molecular cytogenetic organization of $5 \mathrm{~S}$ and $18 \mathrm{~S}-26 \mathrm{~S}$ rDNA loci in white clover (Trifolium repens L.) and related species. Ann. Bot. 83: 199-206.

Baliane, A. 1984. Cultura do urucuzeiro. Rio de Janeiro, EMATER.

Barret, S. D. 2002. Software for scanning microscopy. Proc. Roy. Microscopy Soc. 37: 7-14.

Bauchan, G. R. and Hossain, M. A. 2001. A computerized image analysis system to characterize small plant chromosomes. Microscopy and Analysis 48: 5-7.

Besendorfer, V., Samardzija, M., Zoldo, S. V., Solic, M. E. and Papes, D. 2002. Chromosomal organization of ribosomal genes and NOR-associated heterochromatin, and NOR activity in some populations of Allium commutatum Guss. (Alliaceae). Bot. J. Linn. Soc. 139: 99-108.

Brasileiro-Vidal, A. C., Cuadrado, A., Brammer, S. P., Zanatta, A. C., Prestes, A. M., Moraes-Fernandes, M. I. B. and Guerra, M. 2003. Chromosome characterization in Thinopyrum ponticum (Triticeae, Poaceae) using in situ hybridization with different DNA sequences. Genetics and Molecular Biol. 26: 505-510.

Carvalho, C. R. and Saraiva, L. S. 1993. A new heterochromatin banding pattern revealed by modified HKG banding technique for maize chromossomes. Heredity 70: 515-519.

— and —. 1997. High-resolution HKG-banding in maize mitotic chromosomes. J. Plant Res. 110: 417-420.

Carvalho, J. F. R. P. 2000. (Ph.D>)Thesis, Univ. Fed. de Viçosa, Brazil.

-, Carvalho, C. R. and Otoni, W. C. 2005. In vitro induction of polyploidy in annatto (Bixa orellana). Plant Cell, Tissue 
and Organ Culture 80: 69-75.

—, Waclawovsky, A. J., Del-Filho, N., Pirovani, C. P., Clarindo, W. R., Loureiro, M. E., Carvalho, C. R. and Fontes, E. P. B. 2003. The soybean sucrose binding protein gene family: genomic organization, gene copy number and tissue-specific expression of the $S B P 2$ promoter. J. Exp. Bot. 54: 2643-2653.

Contim, L. A. S., Carvalho, C. R., Martins, F. A. and Freitas, D. V. 2005. Nuclear DNA content and karyotype of Rosewood (Aniba rosaeodora). Genetics and Molecular Biol. 28: 754-757.

Goodpasture, C. and Bloom, S. E. 1975. Visualization of nucleolar organizer regions in mammalian chromosomes using silver staining. Chromosoma 53: 37-50.

Guerra, M. S. 1986. Reviewing the chromosome nomenclature of Levan et al. Rev. Brasil. de Genética 9: 741-743.

Gupta, P. K. and Gupta, S. N. 1991. Cytogenetics of chromosome interchanges in plants. In: Gupta, P. K. and Tsuchiya, T. (eds.). Chromosome engineering in plants: genetics, breeding, evolution. Part A. Elsevier, pp. 87-112.

Guzzo, F., Campagnari, E. and Levi, M. 2000. A new FISH protocol with increased sensitivity for physical mapping with short probes in plants. J. Exp. Bot. 51: 965-970.

Jones, K. 1998. Robertsonian fusion and centric fission in karyotype evolution of higher plants. Bot. Rev. 64: $273-289$.

Hanson, R. E., Islam-Faridi, M. N., Percival, E. A., Crane, C. F., Ji, Y., McKnight, T. D., Stelly, D. M. and Price, H. J. 1996. Distribution of 5S and 18S-28S rDNA loci in a tetraploid cotton (Gossypium hirsulum L.) and its putative diploid ancestors. Chromosoma 105: 55-61.

Krishnan, N. and Ayyangar, K. R. 1987. Taxonomical relationships of Bixa orellana L. Proc. Indian Sci. Congress 74: 5-105.

Leitch, I. J. and Heslop-Harrison, J. S. 1992. Physical mapping of the 18S-5.8S-26S rRNA genes in barley by in situ hibridization. Genome 35: 1013-1018.

Levan, A., Fredga, A. and Sanderberg, A. A. 1964. Nomenclature for centromeric position in chromosome. Hereditas 52: 201-220.

Liu, C. J., King, I. P., Pittaway, T. S., Abbo, S., Reader, S. M., Miller, T. E. and Gale, M. D. 1997. Physical and genetical mapping of rDNA sites in Pennisetum (pearl millet). Heredity 78: 529-531.

Lorenzi, H. 1998. Árvores brasileiras: Manual de identificação e cultivo de plantas arbóreas nativas do Brasil-Segunda edição-Nova Odessa, SP: Editora Plantarum.

Marcon, A. B., Barros, I. C. L. and Guerra, M. 2005. Variation in chromosome numbers, CMA bands and 45S rDNA sites in species of Selaginella (Pteridophyta). Ann. Bot. 95: 271-276.

Melo, N. F. and Guerra, M. 2003. Variability of the 5S and 45S rDNA sites in Passiflora L. species with distinct base chromosome numbers. Ann. Bot. 92: 309-316.

Morais-Cecílio, L., Delgado, M., Jones, R. N. and Viegas, W. 2000. Modification of wheat rDNA loci by rye B chromosomes: a chromatin organization model. Chromosome Res. 8: 341-351.

Morawetz, W. 1986. Remarks on karyological differentiation patterns in tropical woody plants. Plant Systematics and Evolution 152: 49-100.

Mukherjee, P. 1975. Cytotaxonomical studies on Bixa and Flacourtia. Bull. Bot. Soc. Bengal 29: 25-27.

Neumann, P., Pozarkova, D., Vrana, J., Dolezel, J. and Macas, J. 2002. Chromosome sorting and PCR-based physical mapping in pea (Pisum sativum L.). Chromosome Res. 10: 63-71.

Neves, N., Delgado, M., Silva, M., Caperta, A., Morais-Cecílio, L. and Viegas, W. 2005. Ribosomal DNA heterochromatin in plants. Cytogenetics and Genome Res. 109: 104-111.

Oakey, R. J. and Beechey, C. V. 2002. Imprinted genes: identification by chromosome rearrangements and post-genomic strategies. TRENDS in Genetics 18: 350-366.

Ohmido, N., Akiyama, Y. and Fukui, K. 1998. Physical mapping of unique nucleotide sequences in identified rice chromosomes. Plant Molecular Biol. 38: 1043-1052.

Osuji, J. O., Crouch, J., Harrison, G. and Heslop-Harrison, J. S. 1998. Molecular cytogenetics of Musa species, cultivars and hybrids: location of 18S-5.8S-25S and 5S rDNA and telomeric-like sequences. Ann. Bot. 82: 243-248.

Paiva Neto, V. B., Mota, T. R. and Otoni, W. C. 2003. Direct organogenesis from hypocotyl-derived explants of annatto (Bixa orellana L.). Plant Cell Tissue and Organ Culture 80: 32-38.

Rasband, W. 1998. NIH Image is a public domain program developed at the U.S. National Institutes of Health and available on the Internet at http://rsb.info.nib.gov/nib-image/.

Sato, S. 1988. Color differential staining of NOR-associated heterochromatic segments using acridine orange. Stain Technol. 63: 235-240.

Scotter, M. J., Wilson, L. A., Appleton, G. P. and Castle, L. 1998. Analysis of annatto (Bixa orellana) food coloring formulations. 1. Determination of coloring components and colored thermal degradation products by high-performance liquid chromatography with photodiode array detection. J. Agr. Food Chem. 46: 1031-1038.

Simmonds, N. W. 1954. Chromosome behaviour in some tropical plants. Heredity 8: 139-146.

Switonski, M., Szczerbal, I., Skorczyk, A., Yang, F. and Antosik, P. 2003. Robertsonian translocation (8; 14) in an infertile bitch (Canis familiaris). J. Appl. Genetics 44: 525-527. 
Weiss, H. and Maluszynska, J. 2001. Molecular cytogenetic analysis of polyploidization in the anther tapetum of diploid and autotetraploid Arabidopsis thaliana plants. Ann. Bot. 87: 729-735.

Zhang, P., Friebe, B., Lukaszewski, A. J. and Gill, B. S. 2001. The centromere structure in Robertsonian wheat-rye translocation chromosomes indicates that centric breakage-fusion can occur at different positions within primary constriction. Chromosoma 110: 335-344. 